JOTE Volume 2 Nomor 1 Tahun 2020 Halaman 94-100 JOURNAL ON TEACHER EDUCATION

Research \& Learning in Faculty of Education

\title{
UPAYA MENINGKATKAN HASIL BELAJAR BIOLOGI SISWA DENGAN MODEL STAD DI SMK NEGERI 2 MAUMERE TAHUN AJARAN 2019/2020
}

\author{
Hadijah Goba \\ SMK Negeri 2 Maumere, Sikka, Nusa Tenggara Timur \\ Email : gobahadijah69@gmail.com
}

\begin{abstract}
Abstrak
Tujuan penelitian ini adalah untuk mengetahui apakah terdapat peningkatan hasil belajar Biologi siswa dengan menggunakan model Student Teams Achievement Divisions (STAD) yang di variasikan dengan LKS Word Square pada siswa kelas XI API SMK Negeri 2 Maumere. Jenis penelitian ini adalah Penelitian Tindakan Kelas dengan dua siklus untuk materi kompetensi dasar Keterkaitan antara struktur dan fungsi gen, DNA, kromosom dalam proses penurunan/pewarisan. Subjek penelitian adalah siswa kelas XI API SMK Negeri 2 Maumere sebanyak 17 siswa. Analisis data yang dilakukan dalam penelitian ini menggunakan analisis persentase rata-rata hasil belajar siswa. Berdasarkan hasil analisis data diperoleh. Kesimpulan bahwa penerapan model Student Teams Achievement Divisions (STAD) yang divariasikan dengan LKS Word Square meningkatkan hasil belajar siswa kelas XI API SMK Negeri 2 Maumere pada materi kompetensi dasar Keterkaitan antara struktur dan fungsi gen, DNA, kromosom dalam proses penurunan atau pewarisan mata pelajaran Biologi.
\end{abstract}

Kata kunci: Student Teams Achievement Divisions, hasil belajar Biologi

\begin{abstract}
The purpose of this study was to determine whether there was an increase in student learning outcomes using the Student Teams Achievement Divisions (STAD) model, which was varied with LKS Word Square in class XI API SMK Negeri 2 Maumere. The type of this research is Classroom Action Research with two cycles for basic competency material. The relationship between the structure and function of genes, DNA, chromosomes in the inheritance process. The research subjects were 17 students of class XI API SMK Negeri 2 Maumere. The data analysis conducted in this study used an analysis of the average percentage of student learning outcomes. Based on the results of data analysis obtained. The conclusion is that the application of the Student Teams Achievement Divisions (STAD) model varied with LKS Word Square improves student learning outcomes in class XI API SMK Negeri 2 Maumere on basic competency material The relationship between the structure and function of genes, DNA, chromosomes in the process of inheritance in Biology.
\end{abstract}

Keywords: Student Teams Achievement Divisions, Biology learning outcomes 


\section{PENDAHULUAN}

Biologi merupakan salah satu bagian dari IImu Pengetahuan Alam (IPA) yang sangat besar pengaruhnya untuk penguasaan ilmu pengetahuan dan teknologi, khususnya bagi peserta didik. Biologi lebih menekankan kegiatan belajar mengajar, mengembangkan konsep dan keterampilan proses peserta didik dengan berbagai metode mengajar yang sesuai dengan bahan kajian yang diajarkan. Dalam proses pembelajaran Biologi, sangat diperlukan strategi pembelajaran yang tepat yang dapat melibatkan peserta didik seoptimal mungkin baik secara intelektual maupun emosional. Karena pelajaran biologi menekankan pada keterampilan proses.

Keberhasilan proses pembelajaran di kelas dipengaruhi oleh beberapa factor antara lain adalah pendidik dan peserta didik. Selain menguasai materi seorang pendidik juga dituntut untuk menguasai strategi - strategi penyampaian materi tersebut, cara pendidik menciptakan suasana kelas akan berpengaruh terhadap respons peserta didik dalam proses pembelajaran. Apabila pendidik berhasil menciptakan suasana yang menyebabkan peserta didik termotivasi aktif dalam belajar akan memungkinkan terjadi peningkatan hasil belajar. Pendidik biologi di SMK Negeri 2 Maumere selalu merasa belum puas dalam melaksanakan proses pembelajaran. Hambatan yang ditemui salah satunya adalah kelas selalu pasif, motivasi peserta didik untuk menimbulkan interaksi baik antara peserta didik dengan peserta didik maupun peserta didik dengan pendidik, sehingga kelas selalu didominasi oleh pendidik.

Berdasarkan kenyataan yang ada maka peneliti melakukan penelitian tindakan kelas pada mata pelajaran Biologi di SMK Negeri 2 Maumere mengadakan Penelitian Tindakan Kelas untuk memperbaiki strategi pembelajaran yang memungkinkan peserta didik terlibat secara aktif, sehingga motivasi dan aktivitas peserta didik akan meningkat. Keterkaitan antara struktur dan fungsi gen, DNA, kromosom dalam proses penurunan atau pewarisan merupakan materi pembelajaran yang kompleks, sehingga peserta didik mengalami kesulitan dalam memahami materi tersebut, akibatnya hasil belajar peserta didik tahun-tahun sebelumnya belum mencapai target. Pada materi menganalisis keterkaitan antara struktur dan fungsi gen, DNA, kromosom dalam proses penurunan/pewarisan banyak menggunakan istilah yang menyebabkan materi tersebut kurang diminati dan membosankan bagi peserta didik. Kebosanan ini dapat terlihat dari banyaknya peserta didik yang cenderung pasif dan kurang memperhatikan pada saat pendidik mengajar.

Masalah-masalah tersebut menuntut guru untuk lebih inovatif dalam menentukan model pembelajaran. Selama ini cara pembelajaran yang digunakan oleh guru untuk menyampaikan materi keterkaitan antara struktur dan fungsi gen, DNA, kromosom dalam proses penurunan/pewarisan dengan menggunakan media power point dan metode ceramah. Model pembelajaran kooperatif adalah suatu model pembelajaran yang dapat meningkatkan kualitas pembelajaran melalui peningkatan aktivitas peserta didik, interaksi, penguasaan peserta didik terhadap materi pembelajaran serta peningkatan motivasi peserta didik untuk aktif dalam proses pembelajaran. Salah satu pendekatan dari model pembelajaran kooperatif adalah Model Student Teams Achievement Divisions 
(STAD). Metode STAD ini dalam pelaksanaannya adalah mengajak peserta didik untuk belajar secara berkelompok dengan anggota kelompok yang berasal dari campuran tingkat kecerdasan dan jenis kelamin.

Tujuan dari pembagian kelompok dengan ketentuan tersebut adalah agar dalam satu kelompok terdapat peserta didik yang lebih unggul sehingga apabila ada anggota kelompok yang mengalami kesulitan peserta didik tersebut dapat membantu menyelesaikannya. Metode Student Teams Achivement Division (STAD) ini merupakan salah satu metode dalam pembelajaran kooperatif yang untuk pertama kalinya diperkenalkan oleh Robert-Slavin. Metode ini merupakan salah satu metode yang paling sederhana dalam pembelajaran kooperatif dan merupakan sebuah pendekatan yang baik untuk pendidik yang baru mulai menerapkan pembelajaran kooperatif.

Metode ini lebih menekankan berbagai pembelajaran langsung, dan merupakan metode yang mudah untuk diterapkan dalam pembelajaran sains. Seperti dalam kebanyakan metode pembelajaran kooperatif, metode STAD didasarkan pada prinsip bahwa peserta didik bekerja bersama-sama dalam belajar dan bertanggung jawab terhadap belajar teman dan dirinya sendiri Penggunaan metode ini dalam proses pembelajaran sebenarnya sudah banyak digunakan dan dilakukan dalam penelitian. Berdasarkan hasil penelitian dari Lismiati dalam (Renita, 2007) dapat diambil suatu kesimpulan bahwa dalam penggunaan metode STAD dalam pembelajaran mampu meningkatkan hasil belajar peserta didik sebesar $92,84 \%$. Selain itu pembelajaran juga berjalan lebih efektif karena peserta didik bertindak aktif selama kegiatan belajar mengajar berlangsung.

\section{METODE}

Penelitian ini dilaksanakan di SMK Negeri 2 Maumere pada Semester Ganjil Tahun Pelajaran 2019/2020 dari bulan Juli sampai dengan agustus 2019 terhadap peserta didik kelas XI API dengan jumlah siswa sebaganyak 17 siswa yang terdiri dari 14 perempuan dan 3 laki-laki. Peneliti adalah pendidik mata pelajaran Biologi pada kelas XI API. Prosedur Penelitian Tindakan Kelas pada penelitian ini terdiri dari dua siklus secara berkelanjutan pada Semester Ganjil Tahun Pelajaran 2019/2020. Setiap siklus dilaksanakan dalam 2 (dua) kali pertemuan. Pelaksanaan pertemuan tidak mengganggu jadwal pelajaran di kelas. Siklus pertama dilaksanakan pada bulan Juli 2019 dan siklus kedua dilaksanakan pada bulan Agustus 2019. Perencanaan pada kegiatan pembelajaran siklus I didasarkan pada identifikasi masalah yang ditemukan, apakah masalah tersebut terjadi karena kondisi pembelajaran peserta didik atau pendidik. Perencanaan tindakan untuk siklus II didasarkan pada hasil refleksi hasil belajar peserta didik pada kegiatan pembelajaran siklus I. 


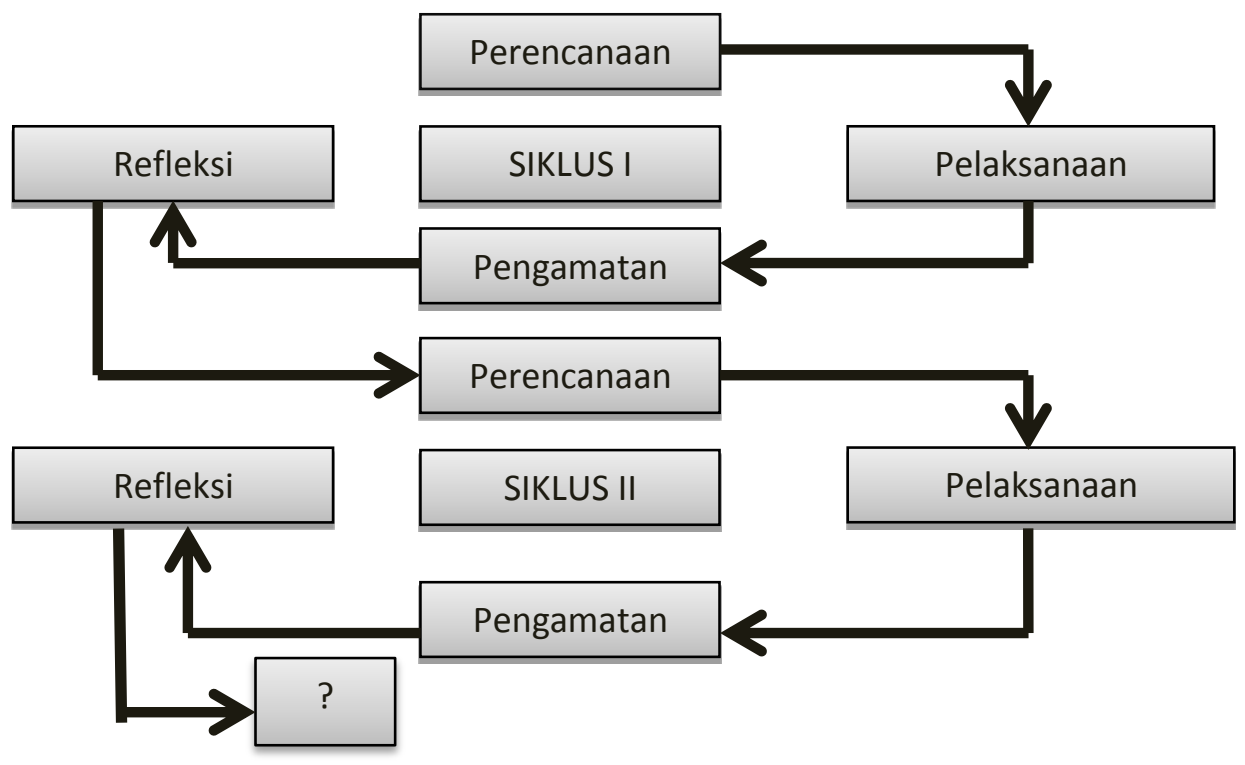

Gambar 1. Desain Penelitian Kemmis-Taggart (Arikunto, 2011)

\section{HASIL DAN PEMBAHASAN}

Pelaksanaan tindakan siklus I dilaksanakan sebanyak 2 kali pertemuan pada bulan juli 2019. Pelaksanaan pembelajaran pada siklus I ini mengacu pada Rencana Pelaksanaan Pembelajaran (RPP) yang telah dipersiapkan. Selama pembelajaran berlangsung aktivitas peserta didik diamati oleh peneliti. Pada akhir siklus I dilakukan tes akhir yang berfungsi untuk mengukur kemampuan peserta didik. Hasil tes siklus I.

Tabel 1. Data hasil belajar siswa siklus I

\begin{tabular}{lll}
\hline \multirow{2}{*}{ No } & Keterangan & Perolehan nilai \\
\hline 1 & Nilai terendah & 55 \\
2 & Nilai tertinggi & 73 \\
3 & Nilai rata - rata kelas & 60 \\
4 & Jumlah peserta didik yang belum tuntas & 10 \\
& belajar & \\
5 & Jumlah peserta didik yang tuntas belajar & 22 \\
6 & Persentase ketuntasan belajar & $68.75 \%$ \\
\hline
\end{tabular}

Berdasarkan data pada tabel di atas diperoleh bahwa nilai terendah peserta didik 55 , nilai tertinggi 73 , nilai rata- rata kelas 60 , jumlah peserta didik yang belum tuntas belajar 10 orang dan peserta didik yang tuntas belajar 22 orang dengan persentase ketuntasan belajar $68,75 \%$. Jika dilihat dari rata-rata hasil belajar secara klasikal, hasil belajar pada siklus I ini juga telah mengalami kenaikan dari $50 \%$ menjadi 68,75\% Meskipun mengalami kenaikan yang baik dari segi rata-rata hasil belajar dan persentase ketuntasan siswa secara klasikal, namun hasil ini belum menjadi harapan, karena rata-rata yang diperoleh belum mencapai nilai KKM 75. Sehingga dengan hasil ini, diperlukan siklus II untuk perbaikan proses pembelajaran lebih baik lagi. 
Tabel 2. Data hasil belajar siswa siklus II

\begin{tabular}{lll}
\hline No & Keterangan & Perolehan \\
\hline 1 & Nilai terendah & 60 \\
2 & Nilai tertinggi & 88 \\
3 & Nilai rata - rata kelas & 75 \\
4 & Jumlah peserta didik yang belum tuntas belajar & 3 \\
5 & Jumlah peserta didik yang tuntas belajar & 29 \\
6 & Persentase ketuntasan belajar & $90.625 \%$ \\
\hline
\end{tabular}

Berdasarkan data pada tabel di atas diperoleh bahwa nilai terendah peserta didik 60 , nilai tertinggi 88 , nilai rata- rata kelas 75 , jumlah peserta didik yang belum tuntas belajar 3 orang dan peserta didik yang tuntas belajar 29 orang dengan persentase ketuntasan belajar $90.625 \%$.

Tabel 3. Perbandingan hasil belajar siklus I dan II

\begin{tabular}{|c|c|c|c|}
\hline No & Keterangan & $\begin{array}{c}\text { Perolehan } \\
\text { nilai siklus } 1\end{array}$ & $\begin{array}{c}\text { Perolehan } \\
\text { nilai siklus 1। }\end{array}$ \\
\hline 1 & Nilai terendah & 55 & 60 \\
\hline 2 & Nilai tertinggi & 73 & 88 \\
\hline 3 & Nilai rata - rata kelas & 60 & 75 \\
\hline 4 & $\begin{array}{c}\text { Jumlah peserta didik yang belum } \\
\text { tuntas belajar }\end{array}$ & 10 & 3 \\
\hline 5 & $\begin{array}{c}\text { Jumlah peserta didik yang tuntas } \\
\text { belajar }\end{array}$ & 22 & 29 \\
\hline 6 & Persentase ketuntasan belajar & $68.75 \%$ & $90.625 \%$ \\
\hline
\end{tabular}

Data tabel 3 dapat di jelaskan bahwa terjadi peningkatan hasil belajar peserta didik secara umum dari siklus I ke siklus II antara lain: Nilai terendah dari 55 menjadi 60, nilai tertinggi dari 73 menjadi 88, nilai rata-rata kelas dari 60 menjadi 75, jumlah peserta didik yang tuntas belajar dari 22 menjadi 29 dan persentase ketuntasan belajar dari $68.75 \%$ menjadi $90.625 \%$. Dengan demikian terjadi peningkatan ketuntasan belajar sebesar $21.88 \%$. Kenaikan tersebut merupakan suatu bukti bahwa pembelajaran kooperatif metode Student Teams Achievement Divisions (STAD) yang divariasikan dengan LKS Word Square dapat meningkatkan hasil belajar Biologi Kompetensi Dasar Menganalisis keterkaitan antara struktur dan fungsi gen, DNA, kromosom dalam proses penurunan/pewarisan.

Sesuai dengan hasil penelitian yang dilakuka oleh Lismiati dalam (Renita, 2007) dapat diambil suatu kesimpulan bahwa dalam penggunaan metode STAD dalam pembelajaran mampu meningkatkan hasil belajar peserta didik sebesar $92,84 \%$. Selain itu pembelajaran juga berjalan lebih efektif karena peserta didik bertindak aktif selama kegiatan belajar mengajar berlangsung.

\section{SIMPULAN}

Pembelajaran kooperatif metode Student Teams Achievement Divisions (STAD) yang divariasikan dengan LKS Word Square. memberikan manfaat bagi peserta didik, di antaranya sebagai berikut: 1) Dapat menciptakan suasana 
belajar aktif dan menyenangkan. 2) Materi pembelajaran yang disampaikan lebih menarik perhatian peserta didik. 3) Dapat meningkatkan hasil belajar peserta didik yang mencapai taraf ketuntasan belajar secara klasikal 90,625\%.

Hendaknya pendidik biologi menerapkan metode STAD dan LKS Word Square pada materi-materi biologi yang lainnya, karena metode STAD yang divariasikan dengan LKS Word Square memudahkan peserta didik dalam memahami materi yang dipelajari. Perlu dilakukan sosialisasi kepada peserta didik terlebih dahulu tentang langkah-langkah pembelajaran metode STAD yang divariasikan dengan LKS Word Square pada peserta didik sebelum pembelajaran agar proses pembelajaran dapat berjalan dengan lancar. Perlu manajemen waktu yang baik terhadap pelaksanaan pembelajaran melalui penerapan metode STAD yang divariasikan dengan LKS Word Square sehingga peserta didik benarbenar dapat memanfaatkan waktu berdiskusi untuk memahami materi yang dipelajari. Perlu diupayakan pengelolaan kelas yang baik oleh pendidik saat proses pembelajaran berlangsung sehingga peserta didik benarbenar aktif dalam proses pembelajaran.

\section{DAFTAR PUSTAKA}

Agus Suprijono, 2009. Cooperative Learning. Yogjakarta

Aunurrahman, 2009. Belajar dan Pembelajaran. Bandung: Afabeta.

E. Kosasih. 2014. Strategi Belajar dan Pembelajaran Implementasi Kurikulum 2013. Bandung: Yrama Widya.

Ibrahim, H.Muslimin. 2000. Pembelajaran Kooperatif. Surabaya: University press

Lie, Anita. 2002. Cooperative Learning. Mempraktikkan Cooperative Learning di Ruang-Ruang Kelas. Jakarta: PT. Grasindo.

M. Chatib. 2012. Orang Tuanya Manusia, Melejitkan Potensi dan Kecerdasan dengan Menghargai Fitrah Setiap Anak. Bandung: Kaifa.

Mansur, S dan Loli. M.P.P. 2019. Upaya Meningkatkan Hasil Belajar Siswa Kelas VII dengan Model Guide Note Taking di SMP San Karlos Habi. Uin Raden Intan Lampung. BIOSFER: Jurnal Tadris Biologi. 10 (1): 21-28. DOI: https://doi.org/10.24042/biosfer.v10i1.3990

Mansur, S. 2018. Pengaruh Pendekatan Jelajah Alam Sekitar (JAS) Terhadap Hasil Belajar Siswa Pada Materi Klasifikasi Mahluk Hidup di SMPK Binawirawan Maumere. Uhamka. Bioeduscience. 2 (1): 74-80. DOI: 10.29405/j.bes/74-80121314

Mansur, S. 2018. Aplikasi Asesmen Dalam Pembelajaran IPA di Kelas IV Sekolah Dasar Negeri Gelogor. Universitas Muhammadiyah Makasar. Jurnal Riset Pendidikan Dasar. 1 (1): 49-55. DOI: http://dx.doi.org/10.26618/jirpd.v1i1.1239

Mansur, S. 2018. Penerapan Model Pembelajaran Kooperatif Tipe STAD untuk Meningkatkan Motivasi dan Hasil Belajar pada Konsep Ekosistem di SMA 
Negeri 2 Maumere. STAI Darul Kamal NW Kembang kerang. Jurnal AlMuta'aliyah.

1

$(1)$ :

117-127.

DOI:

http://ejournal.kopertais4.or.id/sasambo/index.php/mutaaliyah

Nana Sudjana. 2010. Dasar-dasar Proses Belajar Mengajar. Sinar Baru Algesindo: Bandung.

Oemar Hamalik. 2009. Model-model Pembelajaran. Cendekia Insani, Pekanbaru.

P. Suparno. 2012. Filsafat Konstruktivisme dalam Pendidikan. Yogyakarta: Kanisius 